\title{
Prediction of Response to Pegylated Interferon/Ribavirin Combination Therapy for Chronic Hepatitis C Genotypes $2 a$ and $2 b$ and High Viral Load
}

\author{
Soo Ryang Kim ${ }^{\mathrm{a}}$ Ahmed El-Shamy ${ }^{\mathrm{b}, \mathrm{h}}$ Susumu Imoto $^{\mathrm{a}}$ Ke $\mathrm{Ih} \mathrm{Kim}^{\mathrm{a}}$ \\ Kayo Sugimoto $^{\text {a }}$ Soo Ki Kim ${ }^{e}$ Yasuhito Tanaka $^{f}$ Takashi Hatae $^{c}$ \\ Yutaka Hasegawa $^{c}$ Aya Fujinami ${ }^{d}$ Mitsuhiro Ohta $^{d}$ Hak Hotta $^{b}$ \\ Masatoshi Kudog \\ ${ }^{a}$ Department of Gastroenterology, Kobe Asahi Hospital, ${ }^{b}$ Division of Microbiology, Center for Infectious Diseases, \\ Kobe University Graduate School of Medicine, ' Educational Center for Clinical Pharmacy and d Department of \\ Medical Biochemistry, Kobe Pharmaceutical University, Kobe, ${ }^{e}$ Department of Gastroenterology, Kyoto University, \\ Kyoto, ${ }^{f}$ Department of Virology and Liver Unit, Nagoya City University Graduate School of Medical Sciences, \\ Nagoya, and ${ }^{9}$ Department of Gastroenterology and Hepatology, Kinki University School of Medicine, Osakasayama,

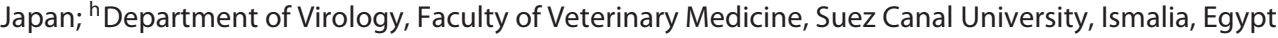

\section{Key Words}

Hepatitis C virus · Genotype 2a · Genotype 2b · IFN/RBV

resistance-determining region $\cdot \mathrm{IL} 28 \mathrm{~B} \cdot$ Sustained

virological response Pegylated IFN/RBV

\begin{abstract}
Objective: We investigated the impact of host genetics represented by the single nucleotide polymorphism (SNP) of the IL28B gene and viral genetic variations within the nonstructural protein $5 \mathrm{~A}$ (NS5A) [including the interferon (IFN)/ ribavirin (RBV) resistance-determining region (IRRDR) and the IFN sensitivity-determining region (ISDR)] on the outcome of pegylated IFN and RBV (PEG-IFN/RBV) treatment. Methods: Sixty-six patients infected with hepatitis $C$ virus (HCV)-2a or HCV-2b who received PEG-IFN/RBV for 24 weeks were examined. Results: In HCV-2a, the major genotype of IL28B SNP showed a tendency toward association with sustained virological response (SVR) and rapid virological response (RVR), and four or more mutations in IRRDR (IRRDR[2a] $\geq 4$ ) and one or more mutations in ISDR plus its
\end{abstract}

\section{KARGER}

E-Mail karger@karger.com

www.karger.com/ddi carboxyl-flanking region (ISDR/+C[2a] $\geq 1$ ) were significantly associated with SVR and RVR. In HCV-2b, one or more mutations in the N-terminal part of IRRDR (IRRDR/N[2b] $\geq 1$ ) were significantly associated with RVR. Multivariate analysis identified the major genotype of IL28B SNP and IRRDR[2a] $\geq 4$ as independent predictive factors of SVR in HCV-2a, with IRRDR[2a] $\geq 4$ being more powerful than the IL28B SNP. Also, IRRDR[2a] $\geq 4$ in HCV-2a and IRRDR/N[2b] $\geq 1$ in HCV-2b were significant determiners of RVR. Conclusion: The NS5A sequence heterogeneity and IL28B SNP are useful factors to predict the sensitivity to PEG-IFN/RBV therapy in HCV-2a and HCV-2b infections.

(c) 2013 S. Karger AG, Basel

\section{Introduction}

In Japan, patients infected with hepatitis $\mathrm{C}$ virus (HCV) genotype $1 \mathrm{~b}$ constitute about $70 \%$ of total $\mathrm{HCV}$ infection; the rest are infected with HCV-2a (25\%) or HCV-2b (5\%) [1]. The protease inhibitor, telaprevir, ap-
(C) 2013 S. Karger AG Basel

$0257-2753 / 13 / 0316-0426 \$ 38.00 / 0$ 
proved in November 2011 by the Ministry of Health, Labor and Welfare, Japan, has shown sustained virological response (SVR) of more than $70 \%$ in $\mathrm{HCV}$ patients with high viral loads of genotype $1 \mathrm{~b}$ [2].

Currently, combination therapy with pegylated interferon and ribavirin (PEG-IFN/RBV) is the standard treatment for chronic hepatitis $\mathrm{C}(\mathrm{CHC})$ patients infected with $\mathrm{HCV}$ $2 \mathrm{a}$ and HCV-2b. Patients infected with HCV genotypes 2 and 3 and treated with PEG-IFN/RBV show higher rates of SVR than those infected with HCV genotype 1 [3-5].

Sequence variations within a region in the nonstructural protein 5A (NS5A) of $\mathrm{HCV}-1 \mathrm{~b}$, defined as the IFN sensitivity-determining region (ISDR) [6] and the IFN/ RBV resistance-determining region (IRRDR) [7], show correlation with IFN responsiveness.

In addition to the NS5A sequence variation, $\mathrm{HCV}$ core protein polymorphism has been proposed as a pretreatment predictor of poor virological response in $\mathrm{HCV}-1 \mathrm{~b}-$ infected patients treated with PEG-IFN/RBV [8]. Host genetic factors associated with response to PEG-IFN/RBV therapy for HCV-1b and a high viral load are single nucleotide polymorphisms (SNPs) located in interleukin (IL)28B (rs8105790, rs11881222, rs8103142, rs28416813, rs4803219, rs8099917, rs7248668 and rs12979860) on chromosome 19 [9-12]. Moreover, on-treatment factors are mainly related to viral kinetics within the first few weeks of treatment [13].

At this stage, however, it is not clear whether NS5A sequence variation, including ISDR and IRRDR, core protein polymorphism, IL28B SNP and viral kinetics, are predictive of treatment outcome in HCV-2a and HCV-2b infections. In this context, we have recently reported that sequence heterogeneity within IRRDR of HCV-2a isolates (IRRDR[2a]) or within its $\mathrm{N}$-terminus of $\mathrm{HCV}-2 \mathrm{~b}$ isolates (IRRDR/N[2b]) is closely correlated with treatment responses, and that sequence heterogeneity within the ISDR plus its carboxyl-flanking region (ISDR/+C[2a]) is significantly associated with SVR in HCV-2a infection [14]. To further expand these observations in the present study, we investigated the effect of host genetics represented by IL28B SNP, the viral kinetics and the viral genetic heterogeneity in NS5A, and the core protein on the outcome of PEG-IFN/ RBV treatment in HCV-2a and HCV-2b infections.

\section{Materials and Methods}

\section{Patients}

A total of 66 patients chronically infected with HCV-2a $(\mathrm{n}=$ $35)$ and HCV-2b $(n=31)$ seen at Kobe Asahi Hospital and Kobe University Hospital, Kobe, Japan, were enrolled in the study. The HCV subtype was determined according to the method of Oka-
Table 1. Proportion of various virological responses of HCV-2aand HCV-2b-infected patients to PEG-IFN/RBV treatment

\begin{tabular}{llll}
\hline Response & \multicolumn{3}{l}{ Proportion } \\
\cline { 2 - 4 } & $\begin{array}{l}\text { All } \\
(\mathrm{n}=66)\end{array}$ & $\begin{array}{l}\text { HCV-2a } \\
(\mathrm{n}=35)\end{array}$ & $\begin{array}{l}\text { HCV-2b } \\
(\mathrm{n}=31)\end{array}$ \\
\hline RVR & $44(67)$ & $23(66)$ & $21(68)$ \\
Non-RVR & $22(33)$ & $12(34)$ & $10(32)$ \\
EVR & $62(94)$ & $34(97)$ & $28(90)$ \\
ETR & $63(95)$ & $34(97)$ & $29(94)$ \\
SVR & $48(73)$ & $28(80)$ & $20(65)$ \\
Non-SVR & $18(27)$ & $7(20)$ & $11(35)$ \\
\hline
\end{tabular}

Figures in parentheses are percentages.

moto et al. [15]. Inclusion and exclusion criteria were as follows, patients demonstrating hemoglobin levels $\geq 11 \mathrm{~g} / \mathrm{dl}$ (women) or $\geq 12 \mathrm{~g} / \mathrm{dl}$ (men), platelet counts $\geq 9 \times 10^{4} / \mathrm{mm}^{3}, \mathrm{HCV}$ RNA $\geq 5.0 \mathrm{log}$ $\mathrm{IU} / \mathrm{ml}$, neutrophil count $\geq 1,500 / \mathrm{mm}^{3}$ and thyroid-stimulating hormone levels within normal limits were included in the study; those demonstrating human immunodeficiency virus or hepatitis $B$ virus coinfection, creatinine clearance $<50 \mathrm{ml} / \mathrm{min}$, cause of liver disease other than $\mathrm{CHC}$, evidence of advanced liver disease, preexisting psychiatric conditions or a history of severe psychiatric disorder were excluded. All of the patients were treated with PEGIFN a-2b (Pegintron ${ }^{\circledR}$; Schering-Plough, Kenilworth, N.)., USA; $1.5 \mathrm{mg}$ per kg body weight, once a week, subcutaneously) and RBV (Rebetol ${ }^{\circledR}$; Schering-Plough; 600-800 mg daily, per os), for 24 weeks according to the standard treatment protocol for Japanese patients established by the hepatitis study group of the Ministry of Health, Labour and Welfare, Japan. The patients received $>80 \%$ of the scheduled dosage of PEG-IFN and RBV. Serum samples were collected at intervals of 4 weeks before, during and after the treatment and tested for HCV RNA and core antigen titers as described [16].

\section{Genetic Variation near the IL28B Gene}

Genetic polymorphism rs8099917 around the IL28B gene was determined by real-time polymerase chain reaction (PCR) with the TaqMan assay (Roche Diagnostics, Tokyo, Japan) [9]. We defined the IL28B major allele as homozygous for the major sequence (TT) and the IL28B minor allele as homozygous (GG) or heterozygous (TG) for the minor sequence.

\section{Viral Kinetics}

The amount of HCV RNA was examined by the COBAS TaqMan HCV test. The patients who cleared HCV viremia (less than $17 \mathrm{IU} / \mathrm{ml}$ ) by week 4 were defined as achieving rapid virological response (RVR). The amount of HCV core antigen was assessed by the IRM assay (Ortho Clinical Diagnostics, Tokyo, Japan) that provides a good correlation between the amount of HCV core antigen and the amount of HCV RNA, as described [17]. The HCV core antigen was measured on days 0 and 7 (week 1) according to the detection limit of $20 \mathrm{fmol} / \mathrm{l}$ established by the manufacturer. Early viral drop was defined as an HCV core antigen level of less than $20 \mathrm{fmol} / \mathrm{l}$. 
Table 2. Demographic characteristics of HCV-2a- and HCV-2b-infected patients with SVR and non-SVR

\begin{tabular}{|c|c|c|c|c|c|c|c|}
\hline \multirow[t]{2}{*}{ Factor } & \multirow[t]{2}{*}{ All } & \multicolumn{3}{|l|}{$\mathrm{HCV}-2 \mathrm{a}$} & \multicolumn{3}{|l|}{$\mathrm{HCV}-2 \mathrm{~b}$} \\
\hline & & SVR & non-SVR & $\begin{array}{l}\text { p value } \\
\text { (SVR vs. } \\
\text { non-SVR) }\end{array}$ & SVR & non-SVR & $\begin{array}{l}\text { p value } \\
\text { (SVR vs. } \\
\text { non-SVR) }\end{array}$ \\
\hline $\mathrm{n}$ & 66 & 28 & 7 & - & 20 & 11 & - \\
\hline Age, years & $52.0 \pm 13.4$ & $50.6 \pm 14.6$ & $57.3 \pm 10.1$ & 0.2006 & $50.6 \pm 13.6$ & $54.6 \pm 10.2$ & 0.5910 \\
\hline Sex (male/female) & $39 / 27$ & $15 / 13$ & $4 / 3$ & 1.0000 & $11 / 9$ & $9 / 2$ & 0.2409 \\
\hline Body weight, kg & $60.4 \pm 8.9$ & $58.6 \pm 8.7$ & $60.0 \pm 10.4$ & 0.7100 & $59.6 \pm 9.2$ & $66.9 \pm 2.5$ & 0.0056 \\
\hline Platelets, $\times 10^{4} / \mathrm{mm}^{3}$ & $18.0 \pm 5.9$ & $19.0 \pm 5.3$ & $15.2 \pm 5.6$ & 0.1170 & $18.1 \pm 5.9$ & $17.1 \pm 7.2$ & 0.7412 \\
\hline Hemoglobin, g/dl & $13.9 \pm 1.8$ & $13.7 \pm 1.8$ & $14.5 \pm 1.8$ & 0.3641 & $13.8 \pm 1.7$ & $14.4 \pm 1.8$ & 0.5351 \\
\hline$\gamma$-GTP, U/l & $47.4 \pm 47.6$ & $35.0 \pm 29.9$ & $45.3 \pm 29.5$ & 0.2829 & $34.2 \pm 29.4$ & $104.7 \pm 74.5$ & 0.0004 \\
\hline ALT, U/1 & $56.8 \pm 64.0$ & $47.6 \pm 38.3$ & $55.4 \pm 41.3$ & 0.5223 & $43.8 \pm 37.4$ & $105.0 \pm 124.7$ & 0.0369 \\
\hline HCV RNA, log IU/ml & $6.1 \pm 0.8$ & $5.9 \pm 0.6$ & $5.7 \pm 1.0$ & 0.8147 & $6.3 \pm 0.8$ & $6.5 \pm 0.4$ & 0.8042 \\
\hline HCV core antigen, fmol/l & $7,659.0 \pm 6,852.9$ & $6,638.8 \pm 6,489.3$ & $5,901.5 \pm 5,963.0$ & 0.8469 & $7,751.2 \pm 6,394.2$ & $10,175.5 \pm 8,464.5$ & 0.4776 \\
\hline Response (RVR/non-RVR) & $44 / 22$ & $21 / 7$ & $2 / 5$ & 0.0331 & $16 / 4$ & $5 / 6$ & 0.1055 \\
\hline IL28B genotype (major/minor) & $60 / 6$ & $26 / 2$ & $5 / 2$ & 0.1710 & $19 / 1$ & $10 / 1$ & 1.0000 \\
\hline
\end{tabular}

Bold p values are significant.

Sequence Analysis of the NS5A and the Core Regions

Sequence analysis of the NS5A and the core regions of HCV was carried out as described $[14,16,18]$. In brief, RNA extracted from serum was reverse transcribed and amplified for NS5A and the core regions of the HCV genome; the resultant RT-PCR products were then subjected to a second round of PCR. The sequences of the amplified fragments were determined by direct sequencing without subcloning. The amino acid (aa) sequences were deduced and aligned. The aa residues of HCV-2a and HCV-2b isolates were numbered according to the polyprotein of HCV-J6 [19] and HCV-J8 [20], respectively.

\section{Statistical Analysis}

Statistical differences in treatment response according to patient baseline parameters of age, body weight, platelets, hemoglobin, $\gamma$-glutamyl transpeptidase ( $\gamma$-GTP), alanine aminotransferase (ALT), HCV RNA load and HCV core antigen were determined by the Mann-Whitney U test for numerical variables and Fisher's exact probability test for categorical variables. Similarly, statistical differences in treatment response according to NS5A and genetic variation near the IL28B gene (genotype TT) were determined by Fisher's exact probability test. Multicolinearity was tested using Spearman's correlation. Spearman's rank correlation analysis was used to test for multicolinearity among candidate variables in the multivariable analysis. When correlation was $>0.5$, only one of the correlated variables was used in the logistic regression model.

\section{Results}

\section{Patient Response to PEG-IFN/RBV Combination \\ Therapy for $H C V-2 a$ and $H C V-2 b$ Infections}

Among the 35 patients infected with HCV-2a, RVR at week 4 was achieved by $66 \%$ (23/35), early virological response (EVR) at week 12 by 97\% (34/35) and end-of- treatment response (ETR) by $97 \%(34 / 35)$. Similarly, among the 31 infected with HCV-2b, RVR was achieved by $68 \%(21 / 31)$, EVR by $90 \%(28 / 31)$ and ETR by $94 \%$ (29/31). SVR was achieved by 28 (80\%) HCV-2a patients and by $20(65 \%) \mathrm{HCV}-2 \mathrm{~b}$ patients. Only 7 (20\%) HCV-2a and $11(35 \%)$ HCV-2b patients were non-SVR. No nullresponse (continuous viremia throughout the treatment and follow-up periods) was observed since all the nonSVR patients achieved HCV-RNA negativity at a certain point in time followed by a rebound in viremia either before or after the treatment course (relapse; table 1).

Patient baseline demographic characteristics and clinical and treatment response are shown in table 2. Among HCV-2a patients, no significant difference was observed between SVR and non-SVR. Among HCV-2b patients, on the other hand, lighter body weight, and lower $\gamma$-GTP and ALT levels showed a significant difference between SVR and non-SVR patients.

\section{Correlation between IL28B and SVR or RVR}

The frequency of allele rs 8099917 among HCV-2a patients was $89 \%$ for the IL28B major genotype (TT; 31/35) and $11 \%$ for the minor genotype (non-TT; $4 / 35$ ); among HCV-2b patients it was $94 \%$ (29/31) for TT and 6\% $(2 / 31)$ for non-TT. Among HCV-2a patients with the IL28B major genotype, SVR was achieved by $84 \%(26 / 31 ; \mathrm{p}=$ $0.1710)$ and RVR by $71 \%(22 / 31 ; \mathrm{p}=0.1061$; table 3$)$. Among HCV-2b patients, on the other hand, SVR was achieved by $66 \%(19 / 29 ; \mathrm{p}=1.0000)$ and RVR by $69 \%$ $(20 / 29 ; p=1.0000$; table 3$)$. Thus, there was a tendency toward SVR and RVR in HCV-2a patients with the IL28B 
Table 3. Correlation between IL28B genotype and SVR or RVR in HCV-2a and HCV-2b infections

\begin{tabular}{llrrrrrr}
\hline & & SVR & Non-SVR & p value & RVR & Non-RVR & p value \\
\hline HCV-2a & IL28B (major; $\mathrm{n}=31)$ & $26(84)$ & $5(16)$ & 0.1710 & $22(71)$ & $9(29)$ \\
& IL28B (nonmajor; $\mathrm{n}=4)$ & $2(50)$ & $2(50)$ & $1(25)$ & $3(75)$ & 0.1061 \\
\hline HCV-2b & IL28B (major; $\mathrm{n}=29)$ & $\begin{aligned} 19(66) \\
1(50)\end{aligned}$ & $\begin{array}{r}10(34) \\
1(50)\end{array}$ & 1.0000 & $\begin{array}{r}20(69) \\
1(50)\end{array}$ & $\begin{array}{r}9(31) \\
1(50)\end{array}$ \\
& IL28B (nonmajor; $\mathrm{n}=2)$ & & & 1.0000 \\
\hline
\end{tabular}

Figures in parentheses are percentages.

Table 4. Correlation between IL28B genotype and SVR or RVR according to IRRDR[2a] $\geq 4$ or IRRDR[2a] $\leq 3$ in HCV-2a infection

\begin{tabular}{|c|c|c|c|c|c|c|c|}
\hline & & SVR & Non-SVR & $\mathrm{p}$ value & RVR & Non-RVR & $\mathrm{p}$ value \\
\hline IRRDR $\geq 4$ & $\begin{array}{l}\text { IL28B (major; } \mathrm{n}=21) \\
\text { IL28B (nonmajor; } \mathrm{n}=2 \text { ) }\end{array}$ & $\begin{array}{r}20(95) \\
1(50)\end{array}$ & $\begin{array}{l}1(5) \\
1(50)\end{array}$ & 0.1700 & $\begin{array}{r}19(90) \\
1(50)\end{array}$ & $\begin{array}{l}2(9) \\
1(50)\end{array}$ & 0.2490 \\
\hline IRRDR $\leq 3$ & $\begin{array}{l}\text { IL28B (major; } \mathrm{n}=10) \\
\text { IL28B (nonmajor; } \mathrm{n}=2 \text { ) }\end{array}$ & $\begin{array}{l}6(60) \\
1(50)\end{array}$ & $\begin{array}{l}4(40) \\
1(50)\end{array}$ & 1.0000 & $\begin{array}{l}3(30) \\
0\end{array}$ & $\begin{array}{l}7(70) \\
2(100)\end{array}$ & 1.0000 \\
\hline
\end{tabular}

Figures in parentheses are percentages.

major genotype, although the difference was not statistically significant, probably due to the small number of the patients examined. Moreover, among HCV-2a patients with the IL28B major genotype, SVR was achieved by $95 \%$ $(20 / 21 ; \mathrm{p}=0.1700)$ and RVR by $90 \%(19 / 21 ; \mathrm{p}=0.2490)$ when involving IRRDR with 4 or more mutations (IRRDR[2a] $\geq 4)$ while SVR was achieved by $60.0 \%(6 / 10$; $\mathrm{p}=1.0000)$ and RVR by $30.0 \%(3 / 10 ; \mathrm{p}=1.0000)$ when involving of IRRDR with 3 or less mutations (IRRDR[2a] $\leq 3$; table 4). Thus, there was a tendency toward SVR and RVR in HCV-2a patients with the IL28B major genotype when involving of IRRDR[2a] $\geq 4$, but not IRRDR[2a] $\leq 3$.

\section{Correlation between Viral Kinetics Including Early Viral Drop and SVR}

SVR was achieved by $91 \%$ (21/23) of HCV-2a-infected patients who achieved RVR, but by only $9 \%(2 / 23)$ of those who did not achieve RVR (table 5). Thus, RVR was significantly associated with SVR in HCV-2a infection ( $p=0.0331$ ). On the other hand, RVR was not significantly associated with SVR in HCV-2b infection ( $\mathrm{p}=0.1055$; table 5).

$\mathrm{HCV}$ core antigen titers were measured one week after the initiation of treatment in $91 \%(32 / 35)$ and $97 \%(30 / 31)$ of patients infected with $\mathrm{HCV}-2 \mathrm{a}$ and $\mathrm{HCV}-2 \mathrm{~b}$, respectively. Patients with the HCV core antigen titer of $<20 \mathrm{fmol} / \mathrm{l}$ after 1 week were considered as achieving early viral drop.
Table 5. Correlation between RVR and SVR in HCV-2a and HCV$2 \mathrm{~b}$ infections

\begin{tabular}{llrll}
\hline & & SVR & Non-SVR & p value \\
\hline HCV-2a & RVR $(\mathrm{n}=23)$ & $21(91)$ & $2(9)$ & \\
& Non-RVR $(\mathrm{n}=12)$ & $7(58)$ & $5(42)$ & $\mathbf{0 . 0 3 3 1}$ \\
\hline HCV-2b & RVR $(\mathrm{n}=21)$ & $16(76)$ & $5(24)$ & \\
& Non-RVR $(\mathrm{n}=10)$ & $4(40)$ & $6(60)$ & 0.1055 \\
\end{tabular}

Figures in parentheses are percentages.

Bold $\mathrm{p}$ values are significant.

As shown in table 6, RVR was achieved by 93\% (13/14) of HCV-2a-infected patients who achieved early viral drop, and by only $44 \%(8 / 18)$ of those who did not. Thus, the early viral drop was significantly associated with RVR ( $\mathrm{p}=$ $0.0075)$ but not with SVR $(p=0.1959)$ in HCV-2a infection. On the other hand, early viral drop was not associated with either RVR ( $p=0.1405)$ or SVR ( $p=0.6328)$ in HCV-2b infection.

\section{Sequence Analysis of NS5A of HCV-2a and HCV-2b}

Alignment of all the NS5A sequences of the HCV-2a genome obtained from pretreatment sera against the consensus sequences previously reported [14] revealed that 
Table 6. Correlation between early viral drop and SVR or RVR in HCV-2a and HCV-2b infections

\begin{tabular}{|c|c|c|c|c|c|c|c|}
\hline & & SVR & Non-SVR & $\mathrm{p}$ value & RVR & Non-RVR & $\mathrm{p}$ value \\
\hline $\mathrm{HCV}-2 \mathrm{a}$ & $\begin{array}{l}\text { HCV core antigen }<20 \mathrm{fmol} / 1 \text { after } 1 \text { week }(\mathrm{n}=14) \\
\mathrm{HCV} \text { core antigen } \geq 20 \mathrm{fmol} / \mathrm{l} \text { after } 1 \text { week }(\mathrm{n}=18)\end{array}$ & $\begin{array}{l}13(93) \\
13(72)\end{array}$ & $\begin{array}{l}1(7) \\
5(28)\end{array}$ & 0.1959 & $\begin{array}{r}13(93) \\
8(44)\end{array}$ & $\begin{array}{c}1(7) \\
10(56)\end{array}$ & 0.0075 \\
\hline $\mathrm{HCV}-2 \mathrm{~b}$ & $\begin{array}{l}\text { HCV core antigen }<20 \mathrm{fmol} / 1 \text { after } 1 \text { week }(\mathrm{n}=6) \\
\text { HCV core antigen } \geq 20 \mathrm{fmol} / 1 \text { after } 1 \text { week }(\mathrm{n}=24)\end{array}$ & $\begin{array}{r}5(83) \\
15(63)\end{array}$ & $\begin{array}{l}1(17) \\
9(37)\end{array}$ & 0.6328 & $\begin{aligned} 6 & (100) \\
15 & (63)\end{aligned}$ & $\begin{array}{l}0 \\
9(37)\end{array}$ & 0.1405 \\
\hline
\end{tabular}

Figures in parentheses are percentages. Bold $\mathrm{p}$ values are significant.

Table 7. Average number of aa mutations within IRRDR[2a], ISDR/+C[2a] and IRRDR/N[2b] of HCV NS5A obtained from pretreatment sera of HCV-2a- and HCV-2b-infected patients with SVR, non-SVR, RVR and non-RVR

\begin{tabular}{llcllll}
\hline NS5A region & \multicolumn{2}{l}{ Mutations, $\mathrm{n}$} & & & \\
\cline { 2 - 7 } & SVR & non-SVR & p value & RVR & non-RVR & p value \\
\hline IRRDR[2a] (aa 2332-2387) & $6.0 \pm 3.9$ & $3.0 \pm 1.2$ & $\mathbf{0 . 0 3 6 1}$ & $6.9 \pm 3.7$ & $2.7 \pm 1.3$ & $\mathbf{0 . 0 0 0 3}$ \\
ISDR/+C[2a] (aa 2232-2262) & $1.8 \pm 2.4$ & $0 \pm 0$ & $\mathbf{0 . 0 0 1 5}$ & $2.0 \pm 2.5$ & $0.4 \pm 0.6$ & $\mathbf{0 . 0 1 0 7}$ \\
IRRDR/N[2b] (aa 2332-2357) & $2.2 \pm 1.6$ & $1.4 \pm 1.5$ & 0.1578 & $2.6 \pm 1.4$ & $0.4 \pm 0.5$ & $\mathbf{0 . 0 0 0 2}$ \\
\hline
\end{tabular}

Bold $\mathrm{p}$ values are significant.

Table 8. Correlation between NS5A sequence heterogeneity and SVR or RVR in HCV-2a and HCV-2b infections

\begin{tabular}{|c|c|c|c|c|c|c|}
\hline Factor & SVR & Non-SVR & $\mathrm{p}$ value & RVR & Non-RVR & $\mathrm{p}$ value \\
\hline $\operatorname{IRRDR}[2 \mathrm{a}] \geq 4(\mathrm{n}=23)$ & $21(91)$ & $2(9)$ & \multirow{2}{*}{0.0331} & $20(87)$ & $3(13)$ & \multirow{2}{*}{0.0005} \\
\hline $\operatorname{IRRDR}[2 \mathrm{a}] \leq 3(\mathrm{n}=12)$ & $7(58)$ & $5(42)$ & & $3(25)$ & $9(75)$ & \\
\hline $\mathrm{ISDR} /+\mathrm{C}[2 \mathrm{a}]=0(\mathrm{n}=14)$ & $7(50)$ & $7(50)$ & 0.0005 & $6(43)$ & $8(57)$ & 0.0313 \\
\hline IRRDR/N $[2 \mathrm{~b}] \geq 1(\mathrm{n}=23)$ & $17(74)$ & $6(26)$ & \multirow{2}{*}{0.0947} & $19(83)$ & $4(17)$ & \multirow{2}{*}{0.0059} \\
\hline IRRDR/N[2b] $=0(\mathrm{n}=8)$ & $3(37)$ & $5(63)$ & & $2(25)$ & $6(75)$ & \\
\hline
\end{tabular}

Figures in parentheses are percentages. Bold p values are significant.

the average number of aa mutations in IRRDR[2a] (RVR $=6.9 \pm 3.7$ vs. non-RVR $=2.7 \pm 1.3 ; \mathrm{p}=0.0003)$ and ISDR/+C[2a] $(2.0 \pm 2.5$ vs. $0.4 \pm 0.6 ; \mathrm{p}=0.0107)$ was significantly larger in the isolates from RVR than in those from non-RVR patients. More importantly, the average number of aa mutations in IRRDR[2a] (SVR $=6.0 \pm 3.9$ vs. non-SVR $=3.0 \pm 1.2 ; \mathrm{p}=0.0361)$ and $\mathrm{ISDR} /+\mathrm{C}[2 \mathrm{a}]$ $(1.8 \pm 2.4$ vs. $0 \pm 0 ; \mathrm{p}=0.0015)$ was significantly larger in SVR than in non-SVR.

Similarly, alignment of all the NS5A sequences of the HCV-2b genome against the consensus sequences [14] revealed that the average number of aa mutations in IRRDR/N[2b] was significantly larger in RVR than in
non-RVR $(2.6 \pm 1.4$ vs. $0.4 \pm 0.5 ; \mathrm{p}=0.0002)$; however, no significant difference was observed between SVR and non-SVR (table 7).

\section{Correlation between NS5A Sequence Heterogeneity} and SVR or RVR in HCV-2a and HCV-2b Infections

Ninety-one percent (21/23) of HCV-2a-infected patients with IRRDR[2a] $\geq 4$ achieved SVR compared to only $58 \%(7 / 12)$ of those with IRRDR[2a] $\leq 3$ (table 8 ). This result suggests that IRRDR[2a] $\geq 4$ was significantly associated with SVR ( $\mathrm{p}=0.0331)$. Similarly, $87 \%(20 / 23)$ of IRRDR[2a] $\geq 4$, but only $25 \%(3 / 12)$ of IRRDR[2a] $\leq 3$, achieved RVR, with the result suggest- 
ing that IRRDR $[2 \mathrm{a}] \geq 4$ was also significantly associated with RVR ( $p=0.0005$; table 8$)$.

Likewise, all of the 21 patients infected with HCV-2a having one or more mutations in ISDR $/+\mathrm{C}(\mathrm{ISDR} /+\mathrm{C}[2 \mathrm{a}]$ $\geq 1)$, but only $50 \%(7 / 14)$ of those with ISDR $/+C[2 \mathrm{a}]=0$, achievedSVR, with the result suggesting that ISDR $/+C[2 \mathrm{a}]$ $\geq 1$ was significantly associated with SVR $(p=0.0005)$. The ISDR/+C[2a] heterogeneity was also significantly associated with RVR $(\mathrm{p}=0.0313)$.

In HCV-2b infection, $83 \%$ (19/23) of patients with IRRDR/N[2b] $\geq 1$ achieved RVR whereas $25 \%(2 / 8)$ of those with IRRDR/N $[2 \mathrm{~b}]=0$ achieved RVR $(\mathrm{p}=0.0059)$. Thus, IRRDR/N $[2 \mathrm{~b}] \geq 1$ was significantly associated with RVR, but not with SVR (table 8).

\section{Correlation between HCV Core Protein Sequence}

Heterogeneity and RVR or SVR

A close correlation between HCV core protein sequence patterns and treatment outcome has been proposed in HCV-1b infection [17, 21]; however, this information is still unclear in HCV-2a and HCV-2b infections. Therefore, in the current study, core regions were obtained from the pretreated sera and the aa sequences deduced and aligned with prototype sequences (HCV-J6 [19] and HCV-J8 [20]). Contrary to reports on HCV-1b infection [8], the residues at positions 70 and 91 are well conserved among HCV-2a and HCV-2b isolates, suggesting no correlation between treatment outcome and these observed residues [14].

\section{Identification of Independent Factors Predictive of $S V R$ in $\mathrm{HCV}-2 \mathrm{a}$ and $\mathrm{HCV}-2 b$ Infections}

To identify significant independent predictors of SVR in HCV-2a and HCV-2b infections, univariate and multivariate logistic regression analyses were carried out using all available data on patient baseline parameters and viral genetic polymorphic factors. In $\mathrm{HCV}-2 \mathrm{a}$ infection, univariate analysis identified two factors, the heterogeneity of IRRDR[2a] ( $\geq 4$ vs. $\leq 3$ ) and RVR, that were significantly associated with SVR. Subsequently, multivariate regression analysis including these factors revealed that IRRDR[2a] heterogeneity $(\mathrm{p}=0.0264)$ platelets $(\mathrm{p}=0.0369)$ and IL28B major genotype $(\mathrm{p}=$ 0.0424 ) were independent factors predictive of SVR (table 9).

In HCV-2b infection, univariate analysis identified two factors, body weight and $\gamma$-GTP levels, that were significantly associated with SVR. In the subsequent multivariate analysis, only the $\gamma$-GTP level $(p=0.0287)$ was identified as an independent factor predictive of SVR in

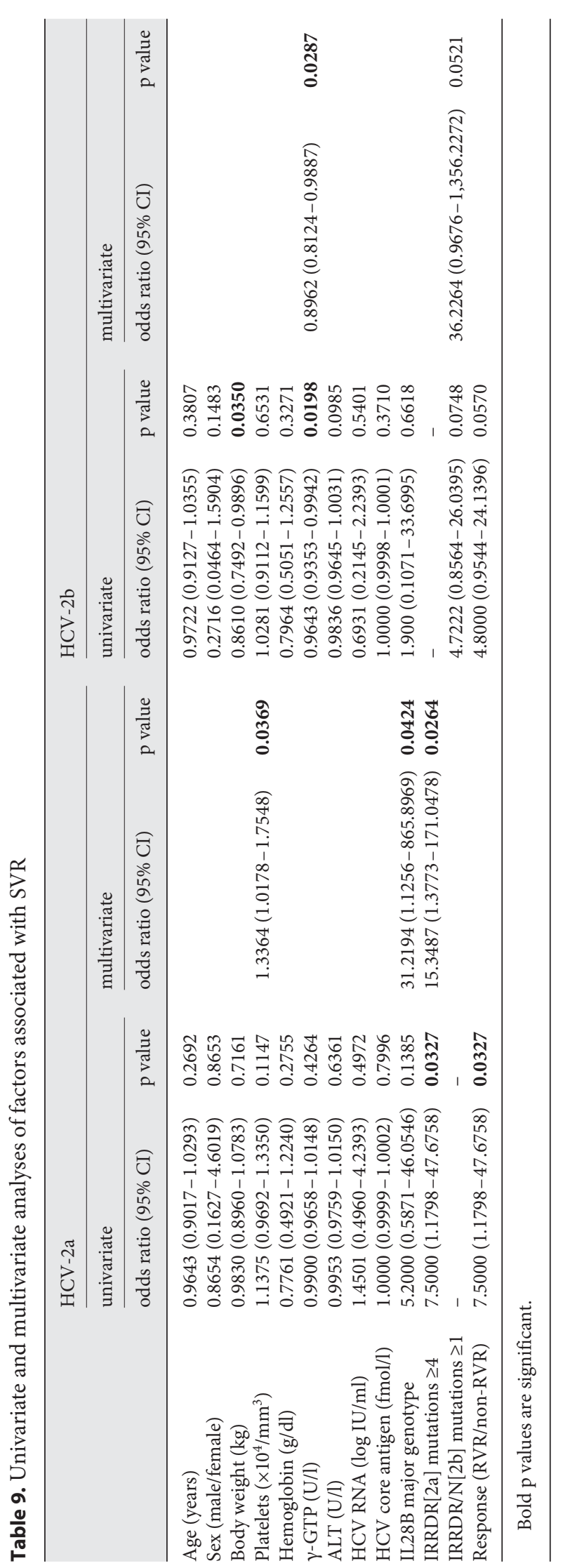


HCV-2b infection. The heterogeneity of IRRDR/N[2b], a viral factor, was identified as significantly associated with RVR ( $\mathrm{p}=0.0064$; data not shown) but not with SVR ( $\mathrm{p}=$ 0.0521 ; table 9 ).

\section{Discussion}

Host factors (such as age, sex, ethnicity, platelets, liver fibrosis and obesity) have been associated with the outcome of PEG-IFN/RBV therapy [22] for HCV genotype 1. Also, the clinical outcome of this therapy for HCV infection is influenced by a number of host factors such as IL28B [9-12] and viral factors including ISDR [17, 23] and core mutations at position 70 in genotype 1 [8].

We have previously compared the impact of IRRDR, ISDR and core mutations as viral genetic polymorphisms, and the IL28B genotype as a host genetic factor, in the clinical outcome of PEG-IFN/RBV therapy - SVR, relapse and nonvirological response (NVR) - for HCV-1b with a high viral load in Japanese patients. IRRDR $\geq 6$ was identified as a viral genetic polymorphism that independently predicts SVR to PEG-IFN/RBV treatment $[7,16$, $17,24]$. The IL28B minor genotype was identified as a host genetic factor that most effectively predicts NVR [24]. On the other hand, ISDR was identified as a factor showing significant correlation with RVR in our previous study, although it has been considered a viral determiner of SVR $[22,23]$.

To date, except for ours [24], few factors, including host and viral factors, and viral kinetics, have been shown to predict the outcome of PEG-IFN RBV therapy for HCV-2a and HCV-2b [25]. In the present study, multivariate analysis identified platelets (OR 1.3364; $\mathrm{p}=$ $0.0369)$, IL28B major genotype (OR 31.2194; $\mathrm{p}=0.0424)$ and IRRDR[2a] $\geq 4$ (OR 15.3487; $\mathrm{p}=0.0264)$, on the one hand, and $\gamma$-GTP (OR 0.8962, $\mathrm{p}=0.0287$ ) on the other, as factors predictive of SVR in patients infected with HCV-2a and HCV-2b, respectively. Similarly, IRRDR[2a] $\geq 4$ (OR 23.8493; $\mathrm{p}=0.0014)$ and IRRDR/ $\mathrm{N}[2 \mathrm{~b}] \geq 1(\mathrm{OR} 44.7766 ; \mathrm{p}=0.064)$ were identified as predictive of RVR in patients infected with HCV-2a and HCV-2b, respectively. Moreover, univariate analysis showed that ISDR/+C[2a] $\geq 1$ was significantly associated with RVR.

Consistent with previous observations of $\mathrm{HCV}-1 \mathrm{~b}$, we have here demonstrated that in Japanese patients sequence heterogeneity within IRRDR is closely correlated with the treatment response of HCV-2a and HCV-2b infections, and that the IL28B major genotype is significant-

ly associated with SVR in HCV-2a infection. Nonetheless, the effect of IL28B SNP appeared to be weaker in HCV-2a and HCV-2b infections than that seen in HCV-1b infections. In HCV-2a, ISDR/+C[2a] was considered a factor related to at least early viral dynamics as shown in $\mathrm{HCV}$ 1b. A mutation at position 70 of the core protein of $\mathrm{HCV}$ $1 \mathrm{~b}$ has been correlated with PEG-IFN/RBV treatment outcome [8]. In the present study, however, we found no significant correlation between core protein polymorphism and treatment outcome in HCV-2a or HCV-2b infection. The sequence conservation observed at position 70 might be the reason for the lack of significant correlation between core protein polymorphism and treatment outcome in HCV-2a and HCV-2b infections.

For the correlation between viral kinetics and treatment outcome, we demonstrated that RVR was related to SVR ( $\mathrm{p}=0.0327)$ in HCV-2a infection; however, we were not able to relate RVR to SVR by multivariate analysis. Furthermore, early viral drop was related to only RVR $(p=0.0075)$ in HCV-2a infection.

In conclusion, the present results suggest the clinical usefulness of the sequence heterogeneity of NS5A in HCV-2a (IRRDR[2a] $\geq 4$ ) and IL28B SNP for determining viral sensitivity to PEG-IFN/RBV therapy given to $\mathrm{HCV}$-2a patients. A large-scale multicenter study is needed to clarify our conclusions.

\section{Acknowledgement}

We are indebted to Mss. Yoshiko Kawamura and Miyuki Taniguchi of Kobe Asahi Hospital for assistance in the preparation of the manuscript.

\section{Disclosure Statement}

The authors have no disclosures to make.

References

Dig Dis 2013;31:426-433 DOI: $10.1159 / 000355381$
1 Enomoto N, Takada A, Nakao T, Date T: There are two major types of hepatitis $\mathrm{C}$ virus in Japan. Biochem Biophys Res Commun 1990;170:1021-1025.

2 Kumada H, Toyota J, Okanoue T, Chayama K, Tsubouchi H, Hayashi N: Telaprevir with peginterferon and ribavirin for treatment-naive patients chronically infected with $\mathrm{HCV}$ of genotype 1 in Japan. J Hepatol 2012;56:78-84.

3 Kurosaki M: How to control HCV-related HCC: a personalized strategy. Liver Cancer 2013;2:167. 
4 Fried MW, Shiffman ML, Reddy KR, Smith C, Marinos G, Gonçales FL Jr, Häussinger D, Diago M, Carosi G, Dhumeaux D, Craxi A, Lin A, Hoffman J, Yu J: Peginterferon alfa-2a plus ribavirin for chronic hepatitis $\mathrm{C}$ virus infection. N Engl J Med 2002;347:975-982.

5 Sarasin-Filipowicz M: Interferon therapy of hepatitis C: molecular insights into success and failure. Swiss Med Wkly 2009;140:3-11.

-6 Enomoto N, Sakuma I, Asahina Y, Kurosaki M, Murakami T, Yamamoto C, Ogura Y, Izumi N, Marumo F, Sato C: Mutations in the nonstructural protein $5 \mathrm{~A}$ gene and response to interferon in patients with chronic hepatitis $\mathrm{C}$ virus $1 \mathrm{~b}$ infection. $\mathrm{N}$ Engl J Med 1996; 334:77-81.

7 El-Shamy A, Nagano-Fujii M, Sasase N, Imoto S, Kim SR, Hotta H: Sequence variation in hepatitis $\mathrm{C}$ virus nonstructural protein $5 \mathrm{~A}$ predicts clinical outcome of pegylated interferon/ribavirin combination therapy. Hepatology 2008;;48:38-47.

-8 Akuta N, Suzuki F, Kawamura Y, Yatsuji H, Sezaki H, Suzuki Y, Hosaka T, Kobayashi M, Kobayashi M, Arase Y, Ikeda K, Kumada H: Predictive factors of early and sustained responses to peginterferon plus ribavirin combination therapy in Japanese patients infected with hepatitis $\mathrm{C}$ virus genotype $1 \mathrm{~b}$ : amino acid substitutions in the core region and lowdensity lipoprotein cholesterol levels. J Hepatol 2007;46:403-410.

-9 Tanaka Y, Nishida N, Sugiyama M, Kurosaki M, Matsuura K, Sakamoto N, Nakagawa M, Korenaga M, Hino K, Hige S, Ito Y, Mita E, Tanaka E, Mochida S, Murawaki Y, Honda M, Sakai A, Hiasa Y, Nishiguchi S, Koike A, Sakaida I, Imamura M, Ito K, Yano K, Masaki $\mathrm{N}$, Sugauchi F, Izumi N, Tokunaga K, Mizokami M: Genome-wide association of $I L 28 B$ with response to pegylated interferon- $\alpha$ and ribavirin therapy for chronic hepatitis $\mathrm{C}$. Nat Genet 2009;41:1105-1109.

10 Ge D, Fellay J, Thompson AJ, Simon JS, Shianna KV, Urban TJ, Heinzen EL, Qiu P, Bertelsen AH, Muir AJ, Sulkowski M, McHutchison JG, Goldstein DB: Genetic variation in $I L 28 B$ predicts hepatitis $C$ treatment-induced viral clearance. Nature 2009;461:399-401.
11 Suppiah V, Moldovan M, Ahlenstiel G, Ber T, Weltman M, Abate ML, Bassendine M, Spengler U, Dore GJ, Powell E, Riordan S, Sheridan D, Smedile A, Fragomeli V, Müller T, Bahlo M, Stewart GJ, Booth DR, George J: IL28B is associated with response to chronic hepatitis $\mathrm{C}$ interferon- $\alpha$ and ribavirin therapy. Nat Genet 2009;41:1100-1104.

12 Rauch A, Kutalik Z, Descombes P, Cai T, Di Iulio J, Mueller T, Bochud M, Battegay M, Bernasconi E, Borovicka J, Colombo S, Cerny A, Dufour JF, Furrer H, Günthard HF, Heim M, Hirschel B, Malinverni R, Moradpour D, Müllhaupt B, Witteck A, Beckmann JS, Berg T, Bergmann S, Negro F, Telenti A, Bochud PY: Genetic variation in $I L 28 B$ is associated with chronic hepatitis $\mathrm{C}$ and treatment failure - a genome-wide association study. Gastroenterology 2010;138:1338-1345.

13 Ferenci P: Predictors of response to therapy for chronic hepatitis C. Semin Liver Dis 2004; 24:525-531.

14 El-Shamy A, Shoji I, Kim SR, Ide Y, Imoto S, Deng L, Yoon S, Fujisawa T, Tani S, Yano Y, Seo Y, Azuma T, Hotta H: Sequence heterogeneity in NS5A of hepatitis C virus genotypes $2 \mathrm{a}$ and $2 \mathrm{~b}$ and clinical outcome of pegylated-interferon/ribavirin therapy. PLoS ONE 2012;7:e30513.

-15 Okamoto H, Sugiyama Y, Okada S, Kurai K, Akahane Y, Sugai Y, Tanaka T, Sato K, Tsuda F, Miyakawa Y: Typing hepatitis $\mathrm{C}$ virus by polymerase chain reaction with type-specific primers: application to clinical surveys and tracing infectious sources. J Gen Virol 1992; 73:673-679.

16 El-Shamy A, Sasayama M, Nagano-Fujii M, Sasase N, Imoto S, Kim SR, Hotta H: Prediction of efficient virological response to pegylated interferon/ribavirin combination therapy by NS5A sequences of hepatitis C virus and anti-NS5A antibodies in pre-treatment sera. Microbiol Immunol 2007;51:471482.

17 El-Shamy A, Kim SR, Ide YH, Sasase N, Imoto S, Deng L, Shoji I, Hotta H: Polymorphisms of hepatitis $\mathrm{C}$ virus non-structural protein $5 \mathrm{~A}$ and core proteins and clinical outcome of pegylated-interferon/ribavirin combination therapy. Intervirology 2012;55:1-11.

-18 Lusida MI, Nagano-Fujii M, Nidom CA, Soetjipto, Handajani R, Fujita T, Oka K, Hotta $\mathrm{H}$ : Correlation between mutations in the interferon sensitivity-determining region of NS5A protein and viral load of hepatitis $\mathrm{C}$ virus subtypes $1 \mathrm{~b}, 1 \mathrm{c}$, and 2a. J Clin Microbiol 2001;39:3858-3864.
9 Okamoto H, Okada S, Sugiyama Y, Kurai K, Iizuka $\mathrm{H}$, Machida A, Miyakawa Y, Mayumi M: Nucleotide sequence of the genomic RNA of hepatitis $\mathrm{C}$ virus isolated from a human carrier: comparison with reported isolates for conserved and divergent regions. J Gen Virol 1991;72:2697-2704.

-20 Okamoto H, Kurai K, Okada S, Yamamoto K, Lizuka H, Tanaka T, Fukuda S, Tsuda F, Mishiro S: Full-length sequence of a hepatitis $\mathrm{C}$ virus genome having poor homology to reported isolates: comparative study of four distinct genotypes. Virology 1992;188:331-341.

21 Akuta N, Suzuki F, Hirakawa M, Kawamura Y, Yatsuji H, Sezaki H, Suzuki Y, Hosaka T, Kobayashi M, Kobayashi M, Saitoh S, Arase Y, Ikeda K, Kumada H: Association of amino acid substitution pattern in core protein of hepatitis $C$ virus genotype 2a high viral load and virological response to interferon-ribavirin combination therapy. Intervirology 2009; 52:301-309.

22 Kurosaki M, Sakamoto N, Iwasaki M, Sakamoto M, Suzuki Y, Hiramatsu N, Sugauchi F, Yatsuhashi H, Izumi N: Pretreatment prediction of response to peginterferon plus ribavirin therapy in genotype 1 chronic hepatitis $\mathrm{C}$ using data mining analysis. J Gastroenterol 2011;46:401-409.

23 Fukuhara T, Taketomi A, Okano S, Ikegami T, Soejima Y, Shirabe K, Maehara Y: Mutations in hepatitis $C$ virus genotype $1 \mathrm{~b}$ and the sensitivity of interferon-ribavirin therapy after liver transplantation. J Hepatol 2010;52: 672-680.

24 Kim SR, El-Shamy A, Imoto S, Kim KI, Ide YH, Deng L, Shoji I, Tanaka Y, Hasegawa Y, Ota M, Hotta H: Prediction of response to pegylated interferon/ribavirin combination therapy for chronic hepatitis $\mathrm{C}$ genotype $1 \mathrm{~b}$ and high viral load. J Gastroenterol 2012;47: 1143-1151.

25 Kawaoka T, Hayes CN, Ohishi W, Ochi H, Maekawa T, Abe H, Tsuge M, Mitsui F, Hiraga $N$, Imamura $M$, Takahashi S, Kubo $M$, Tsunoda T, Nakamura Y, Kumada H, Chayama K: Predictive value of the IL28B polymorphism on the effect of interferon therapy in chronic hepatitis $\mathrm{C}$ patients with genotypes $2 \mathrm{a}$ and 2b. J Hepatol 2011;54:408-414. 